\title{
Exploring Processes for Customer Value Insights, Supply Chain Learning and Innovation An International Study
}

Flint, Daniel J.; Larsson, Everth; Gammelgaard, Britta

\author{
Document Version \\ Final published version \\ Published in: \\ Journal of Business Logistics \\ DOI: \\ 10.1002/j.2158-1592.2008.tb00078.x \\ Publication date: \\ 2008 \\ License \\ Unspecified
}

Citation for published version (APA):

Flint, D. J., Larsson, E., \& Gammelgaard, B. (2008). Exploring Processes for Customer Value Insights, Supply Chain Learning and Innovation: An International Study. Journal of Business Logistics, 29(1), $257-281$. https://doi.org/10.1002/j.2158-1592.2008.tb00078.x

Link to publication in CBS Research Portal

\section{General rights}

Copyright and moral rights for the publications made accessible in the public portal are retained by the authors and/or other copyright owners and it is a condition of accessing publications that users recognise and abide by the legal requirements associated with these rights.

\section{Take down policy}

If you believe that this document breaches copyright please contact us (research.lib@cbs.dk) providing details, and we will remove access to the work immediately and investigate your claim. 


\title{
EXPLORING PROCESSES FOR CUSTOMER VALUE INSIGHTS, SUPPLY CHAIN LEARNING AND INNOVATION: AN INTERNATIONAL STUDY
}

\author{
by \\ Daniel J. Flint \\ University of Tennessee \\ Everth Larsson \\ Lund University \\ and \\ Britta Gammelgaard \\ Copenhagen Business School
}

\section{INTRODUCTION}

Supply chain management, and within it, logistics management, involves designing, managing and improving product and service flow processes that span functions, organizations and countries in attempts to serve downstream customers' and ultimately end-use customers' ever changing desires, needs and expectations, i.e., to help create superior value for and with them over time. Logistics service providers and logistics managers within other organizations concerned with providing this superior customer value must rely, at a minimum, on input from marketing and sales for information about what customers value as well as draw upon their own functional interactions with and data on customers' buying behavior. Due to the lead times required for even highly agile and responsive supply chain processes, supply chain managers must constantly look into the future to anticipate demand. Developing innovative supply chain processes and solutions requires even greater lead time that goes beyond demand anticipation. Since some of these innovations are focused on the marketplace, i.e., improving value propositions for downstream customers, organizations need to anticipate what customers will value in addition to focusing on demand for what they currently value. This is a multi-functional and even multi-organizational problem, not merely a marketing one. If supply chain and logistics managers are expected to create innovations that better serve customers through cost reductions or improved service and if they are expected to support product innovations, then they ought to be intimately aware of if not involved in innovation processes.

A process-orientation of the firm and supply chain would argue that most business functions and organizations within the supply chain have at least a partial role to play in understanding, interpreting and responding to what customers value (Hammer 2001; Larsson and Ljungberg 2006; Mentzer et al. 2001; Quinn 2001). The current highly dynamic global marketplace is reflected in emergent, dissolving, and merging suppliers, competitors and customers, as well as a challenging regulatory, economic and political landscape. As such, supply chain and logistics managers are continuously revisiting and altering strategies and tactics for keeping up with and meeting customers' expectations. One way of addressing this dynamic environment is through innovation. Innovation can be continuous or discontinuous, incremental or disruptive. It can apply to cost improvements, process improvements, product or service line extensions, new uses, new markets, new categories, or new to the world technologies. Supply chain and logistics managers play a role in innovation in at least two ways, i.e., one by developing innovations in supply chain management processes that themselves help create a differential advantage for firms and ideally supply chains and two, by superior execution in support of product innovations developed by OEMs (original equipment manufacturers). To do either, supply chain and logistics managers partly draw upon insights to customers' demands, 
desires, expectations, and benefit-sacrifice tradeoffs, i.e., what they value. Additionally, developing innovative supply chain solutions or means of supporting new product launches involves collaboration and coordination across functions and organizations, processes that potentially can result in supply chain learning. We define these terms further in subsequent sections.

\section{Innovation and Competitive Advantage}

Supply chain management and logistics professionals have voiced their interest in innovation through the Council of Supply Chain Management Professionals (CSCMP) recent calls for examples of supply chain innovations, its support for presentation tracks on innovation at its annual conference, and publication of articles in this journal about innovation (Fawcett, Smith, and Cooper 1997; Flint et al. 2005; Scannell, Vickery, and Dröge 2000). Similarly, a 2004 report of the European Logistics Association (ELA) in partnership with A.T. Kearney Management Consultants (ELA 2004) discussed the importance of supply chain managers being involved in transforming superior capabilities and resources "into positional competitive advantage such as lower costs or superior customer value through differentiation" (ELA 2004, p. 3). That report argues, consistent with our research and that of many others, that differentiation (that is valued by customers) triggers customer satisfaction, customer loyalty, higher market share, and profitability.

Rapidly changing global customer demands and expectations lie behind firm's intense need to continuously search for differential advantage (Day 1994; ELA 2004). The ELA survey highlights distinct "levers" that can help in this regard, two of which are collaboration throughout the supply chain, i.e., sharing and utilizing information across organizational boundaries, and value chain management from product design through sales and from initial suppliers through to end-users. Both of these levers are cross functional process-oriented. The processes of gaining customer insights, learning, and innovating are critical. None of them are merely one department's responsibility. Responsibilities, roles and awareness span functions.

Recent research has begun to explore the relationships between customer insights, inter-organizational learning, and innovation (Flint et al. 2005; Hurly and Hult 1998). We elaborate on and test this notion of inter-organizational learning in this article expanding it to the concept of supply chain learning and specifically mean multiple organizations developing, sharing and collaborating about supply chain and product problems and potential solutions jointly across organizations within a supply chain. Here we are specifically addressing two or three supply chain partners working together in a learning environment in order to develop innovations for the management of product and information flows that better serve changing downstream customers' needs. We are not arguing that entire supply chains are collaborating and competing against distinctly different and entire supply chains. Most firms belong to multiple supply chains and deal with many of the same customers and suppliers. However, researchers have found that knowledge is a strategic resource (Hult et al 2006), and can serve as a significant source of competitive advantage (Gupta and Govindarajan 2000). Inter-firm collaboration enhances this knowledge generation process (Lane and Lubatkin 1998), as does ensuring that supply chain partners, e.g., suppliers and customers, adopt an organizational learning orientation.

Let's draw a simple logic path. We know that logistics and supply chain management excellence are crucial for customer satisfaction across industries and market segments (Ellinger, Ellinger, and Keller 2002; Mentzer, Flint, and Hult 2001), and that customer satisfaction is critical to customer loyalty, with loyalty being critical for profitability (Reichheld 1996). We also know that understanding customers more deeply than competitors, including the specific and relative importance of supply chain and logistics services, is critical to customer satisfaction and loyalty (ELA 2004; Gale 1994; Mentzer, Flint, and Hult 2001; Woodruff and Gardial 1996). Additionally, it appears clear that innovation in both products and services can serve as a differential advantage if valued by certain customer segments (Kahn 2001), thus providing one of several routes to customer acquisition, satisfaction, and loyalty. But we also know that successful innovative customer solutions (as delivered through innovative products and services) draw upon processes that rely on an ability to look into the future at what customers are likely to value (Flint et al. 2005; Woodruff and Gardial 1996).

One need not look far to find examples of supply chain innovations that stem from a customer focus and interorganizational learning. For example, Kraft successfully collaborated with Safeway to manage joint organizational learning efforts focused on supply chain innovations (Kelley and Littman 2005). Initiated by a Kraft supply chain director, a collaboration process was developed that led to a vendor managed inventory system, which evolved into a 
cross docking arrangement and finally a new pallet system. The supply chain innovations eliminated the need for storing and shelving of critical products and helped to increase revenue by 167 percent for one product, Capri Sun. Elsewhere many similar examples can be found, such as Ikea, the Swedish-based home furnishings retailer which provides an ongoing example of how both suppliers and customers are participants in supply chain innovations. One innovation developed long ago was to let consumers execute final assembly of purchased furnishings. Another was to work the entire supply chain toward flat packages, reducing storage and transportation costs and increasing the levels of standardization and throughput. These supply innovations drove joint learning processes and supply flow innovations across multiple tier one and two suppliers. For example, fittings are designed not only for function and aesthetics, but also to conform to handling and transport requirements all along the supply chain. The close collaboration, coordination, integration and joint learning efforts across multiple partners, represents a good example of supply chain learning and innovation.

\section{Research Purpose}

Supply chain and logistics managers can help organizations look into the future at what customers are likely to value in a variety ways, if by doing nothing more than participating in customer meetings and listening with a different mindset than traditional marketers do. What we know less about is the extent to which firms are engaged in processes for (1) projecting what customers will value in the future, (2) supply chain learning, and (3) innovation management and the strength of the correlations among these sets of processes as presented by recent authors (e.g., Flint et al. 2005). This paper reports on research aimed at addressing this gap.

Recent developments concerning logistics innovation contend that innovation sometimes stems from formal processes aimed at capturing, analyzing and interpreting future-oriented customer data, "clues," and using the resultant insights to motivate internal discussions about customers, supply chain learning, and innovation (Flint et al, 2005). Here, customer value insight activities refer to "clue gathering" from multiple sources of customer data over time to develop insights about where customers might be headed. Additionally, the authors argue that logistics innovations emerge from a process whereby managers from multiple organizations in a supply chain formally gather data that suggests customers' desires are changing. They then interact in an active learning environment focused on insights developed from those data, and leverage this insight to develop innovative supply chain solutions (see Figure 1).

FIGURE 1

A LOGISTICS INNOVATION PROCESS ${ }^{a}$

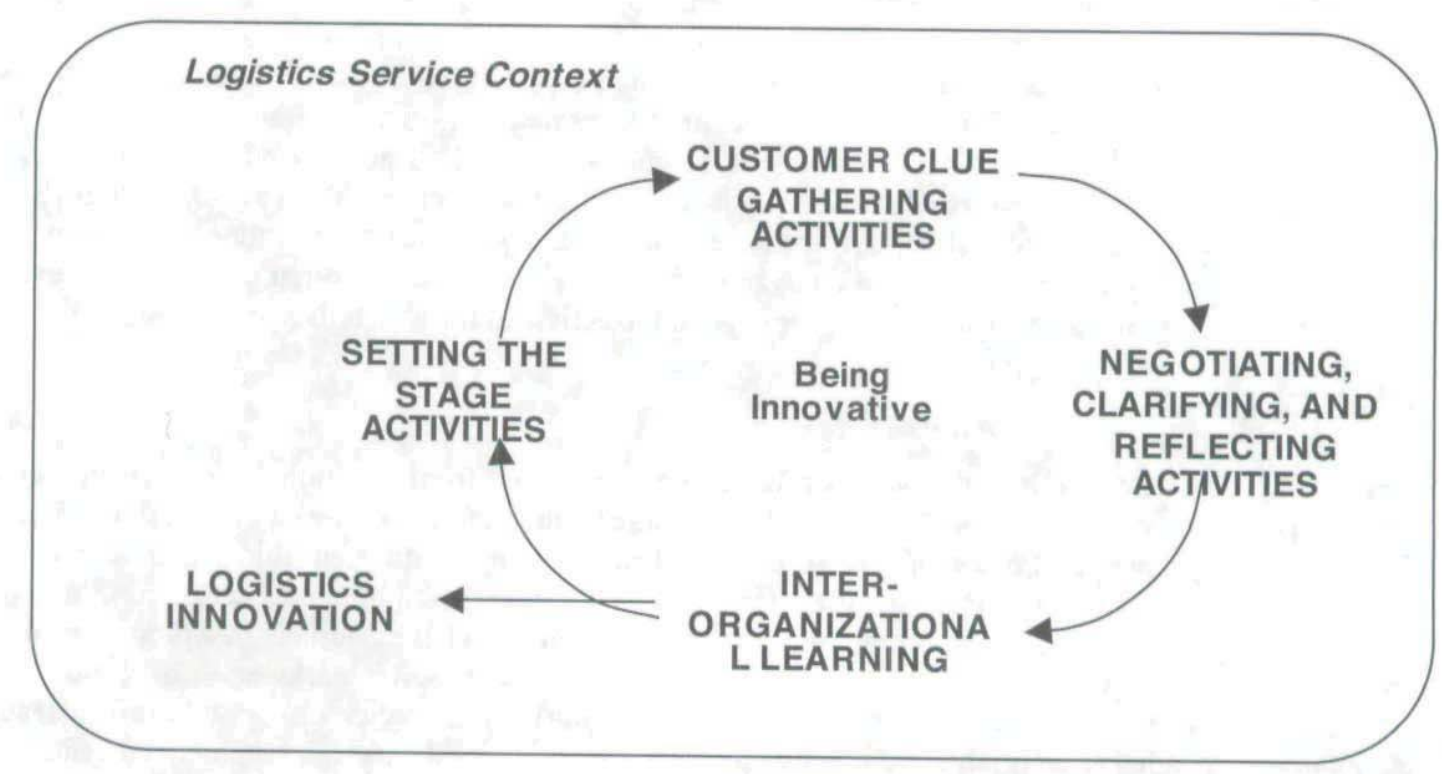

"Note : Source: Flint et al. 2005, p. 127. 
In Figure 1, logistics and supply chain managers may be involved in gathering, interpreting and responding to customer insights as are marketing and sales, even if the market research aspects are still controlled by the marketing function within organizations. The model seems logical. However, it was developed qualitatively and has yet to be validated at an aggregate level.

Therefore, we set out to:

- assess the extent to which firms are actually engaged in market and customer research specifically on changing customer desires, are engaged in processes aimed at encouraging supply chain learning, and are engaged in innovation management activities,

- assess the correlation among these activities, e.g., do firms engaged in these customer value insight processes also tend to engage in discussions about customers, supply chain learning activities, and innovation activities to a greater extent, and

- do these processes impact performance perceptions?

We felt it important to explore these issues staying relatively close to the original model in Figure 1 partly to quantitatively test that model which was developed through detailed qualitative methods, but more broadly, to improve our understanding of these relationships which will in turn improve the advice we provide to supply chain and logistics managers regarding roles they should play within innovation processes. The next sections review relevant literature to support the theoretical model, hypotheses and operational measures, report on our research findings and finally discuss implications for managers and researchers.

\section{LITERATURE REVIEW}

In this section we review literature in the areas related to components of Figure 1, namely what we are calling setting the stage, customer value insights (i.e., in Fig. 1, "customer clue gathering activities" and "negotiating, clarifying, and reflecting activities"), supply chain learning, and innovation.

\section{Setting the Stage}

Figure 1 depicts an initial set of activities called "setting the stage activities." In Flint et al. (2005) this referred to laying the ground work for interacting with supply chain partners, gathering customer data, monitoring the market environment and analyzing customer data. We interpret this to mean primarily training managers and acquiring the resources and capabilities for engaging in processes aimed at developing customer value insights. It seems that training managers might be the most critical aspect because the resources required for market research are readily available in most organizations today. Beyond being common sense, this idea of laying groundwork is readily involved in any discussion of product planning or market research (Gale 1994; Jaworski and Kohli 1993; Kahn 2001). However, in this context, it is noteworthy that the qualitative research reported by Flint et al. (2005) bears out how critical it is to prepare people and organizations to be innovative and to actively look for clues to what customers might value in the future. As such, we thought it important to capture the extent of setting the stage processes for capturing customer value insight, defined here as the degree to which organizations train managers to capture primary and secondary customer data and analyze that data. Evidence suggests that organizations expend a great deal of effort to (1) set such a stage and then (2) engage in the activities for which they were designed.

\section{Customer Value Insights}

The concept of customer value insights here is related to but extended from traditional voice of the customer concepts. The phrase "voice of the customer" has taken on baggage from a number of areas within business, namely operations, product development and marketing. To each, the phrase may mean different things. To operations and product development managers it may mean specific, attribute-based customer requirements reflected in a house of quality matrix or six sigma initiative. To a product developer it may mean what customers say they want through focus groups, interviews, observations and surveys about new product offerings. To marketers it may mean results from customer satisfaction surveys, sales call reports, and customer profiles in service centers that reflect reactions to past performance or insights from qualitative and quantitative methods aimed at what customers currently value. Voice of the customer data can and do reside all over the organization, even within logistics systems. Even though 
firms often find it time consuming and expensive to pull together all of these forms of customer related data into one system that facilitates holistic views of customers and cross functional discussions about customers, those that invest the time and financial resources to do so find high returns on their investments (Gulati and Oldroyd 2005).

At times, the voice of the customer includes insights to what customers are likely to value in the future. But they are rarely statements of what customers actually say and are more often interpretations of what customers say, what they don't say, and what they do (i.e., their behaviors) that suggest what products and services they may value in the future. The customer value insights concept we use here is along these lines and is discussed by some researchers (Beverland, Farrelly, and Woodhatch 2004; Beverland and Lockshin 2003; Flint et al. 2005; Woodruff and Gardial 1996) as an important distinction from traditional voice of the customer insights. In order to use voice of the customer data for innovation, managers must see patterns and trends with individual customer relationships and customer segments over time that point toward future desires not merely see current desires or evaluations of suppliers' past performance (e.g., satisfaction). The processes aimed at developing these insights at the macro-level have been referred to as trend analysis by futurists (Hamel and Prahalad 1994; Popcorn 1991) or at the micro level as customer value prediction (Woodruff and Gardial 1996), market sensing (Day 1994), or customer clue gathering (Flint et al. 2005). Market orientation researchers have alluded to anticipation of what customers will value as well (Jaworski and Kohli 1993; Narver, Slater, and MacLachan 2004; Slater and Narver 2000), although this is often interpreted as demand anticipation not new desired value anticipation.

Product and service innovation ideas can emerge from many places within and outside of firms. One critical source of new product (defined broadly as both products and services) ideas is this notion of customer value insights (Cooper 1999; Kahn 2001). Marketing and sales functions traditionally have the best access to customers and methods for capturing these kinds of data, but the information has relevance for all other functions and upstream suppliers (Maltz and Kohli 1996; Slater and Narver 2000). However, logisticians are also increasingly becoming involved earlier in product development processes and organizational learning processes due to the critical roles packaging, storage and transportation play in the efficiency and effectiveness of those products in the marketplace (Zacharia and Mentzer 2004). Even though logisticians are rarely responsible for managing voice of the customer processes directly or in their entirety, they certainly possess logistics related insights that should impact new product development processes.

Other functions are increasingly becoming involved in innovation as well reflecting significant inter-functional coordination. As some have noted, both inter-functional coordination and organizational learning have become critical to the success of product development and launch processes (Cooper 1999; Dröge, Jayaram, and Vickery 2000; Ellinger, Ellinger, and Keller 2002; Griffin 1997a, 1997b; Moorman and Slotegraaf 1999). Clearly, developing market intelligence and engaging in cross-functional discussions about market insights have become critical for most organizations.

We are interested in the extent to which organizations utilize processes like these aimed at developing customer value insights. Since we know that market sensing involves gathering primary and secondary market data and analyzing those data (Jaworski and Kohli 1993; Kahn 2001; Narver, Slater, and MacLachan 2004; Slater and Narver 2000; Woodruff and Gardial 1996), our research explored the extent to which organizations utilized four distinct sets of processes, i.e., direct customer interactions, customer satisfaction/complaint systems, customer market environment monitoring, and customer data analysis, primarily focused on changes in customer value perceptions over time. The extent of direct customer interaction concept we define here as the degree to which organizations interact with customers in customer meetings gathering intelligence about what they value and how what they value might be changing. The extent of customer market environment monitoring concept we define here as the degree to which organizations utilize processes for monitoring (simply watching for) changes in what customers value. The extent of customer satisfaction/complaint processes concept we define here as the degree to which firms have formal customer satisfaction and complaint processes and use them to look for clues to changes in what customers value. The extent of customer buying and secondary data analysis concept we define here as the degree to which organizations utilize processes for analyzing primary buying data and secondary data to gain insights about what customers might value in the future. These four concepts capture, in our minds, what was discussed by Flint et al (2005) with respect to "customer clue gathering activities," also reflected in Figure 1. Similarly, we define the extent of customer insight discussions concept here as the degree to which organizations engage in cross-functional dialogue about customer value insights, referred to as "negotiating, clarifying and reflecting activities" in Figure 1. 
Our interpretation of the literature discussed here as it relates to Figure 1 leads us to the following hypotheses related to setting the stage:

\section{$\mathrm{H}_{1}$ : Setting the Stage}

$\mathrm{H}_{\mathrm{la}}$ : The more firms set a stage for capturing customer value insights, the greater the extent of customer interactions.

$\mathrm{H}_{1 \mathrm{~b}}$ : The more firms set a stage for capturing customer value insights, the greater the extent of customer market environment monitoring.

$\mathrm{H}_{1 \mathrm{c}}$ : The more firms set a stage for capturing customer value insights, the more likely they are to have formal customer satisfaction/complaint processes.

The four concepts relating to gathering primary and secondary customer data and analyzing this data are obviously related. If firms invest in processes for gathering buying and satisfaction data, and prior to that, train managers in the analyses of that data, then it seems logical that they are more likely to engage in analysis processes. Additionally, organizations who engage in customer face-to-face meetings often collect notes and data from those meetings. One would expect those notes to result in more analyses of what was heard in connection with analyses of buying data. As such, we hypothesize that:

$\mathrm{H}_{2 \mathrm{a}}$ : The greater the extent of customer market environment monitoring, the greater the extent of customer buying and secondary data analysis.

$\mathrm{H}_{3 \mathrm{a}}$ : The greater the extent of customer satisfaction/complaint processes, the greater the extent of customer buying and secondary data analysis.

$\mathrm{H}_{4 \mathrm{a}}$ : The greater the extent of direct customer interactions, the greater the extent of customer buying and secondary data analysis.

It also seems logical that when organizations lay the groundwork for gathering and analyzing market data, they are likely to discuss it (Hurley and Hult 1998; Jaworski and Kohli 1993):

$\mathrm{H}_{2 \mathrm{~b}}$ : The greater the extent of customer market environment monitoring, the greater will be the extent of customer insight discussions.

$\mathrm{H}_{3 \mathrm{~b}}$ : The greater the extent of customer buying and secondary data analysis, the greater will be the extent of customer insight discussions.

$\mathrm{H}_{4 \mathrm{~b}}$ : The greater the extent of direct customer interactions, the greater will be the extent of customer insight discussions.

Notice how we have expanded on Figure 1 with our hypotheses and constructs by expanding the customer clue gathering category into distinct sets of processes to arrive at Figure 2. We explain the remaining hypotheses next. 
FIGURE 2

AN OPERATIONAL MODEL OF THE INNOVATION PROCESS IN FIG. 1

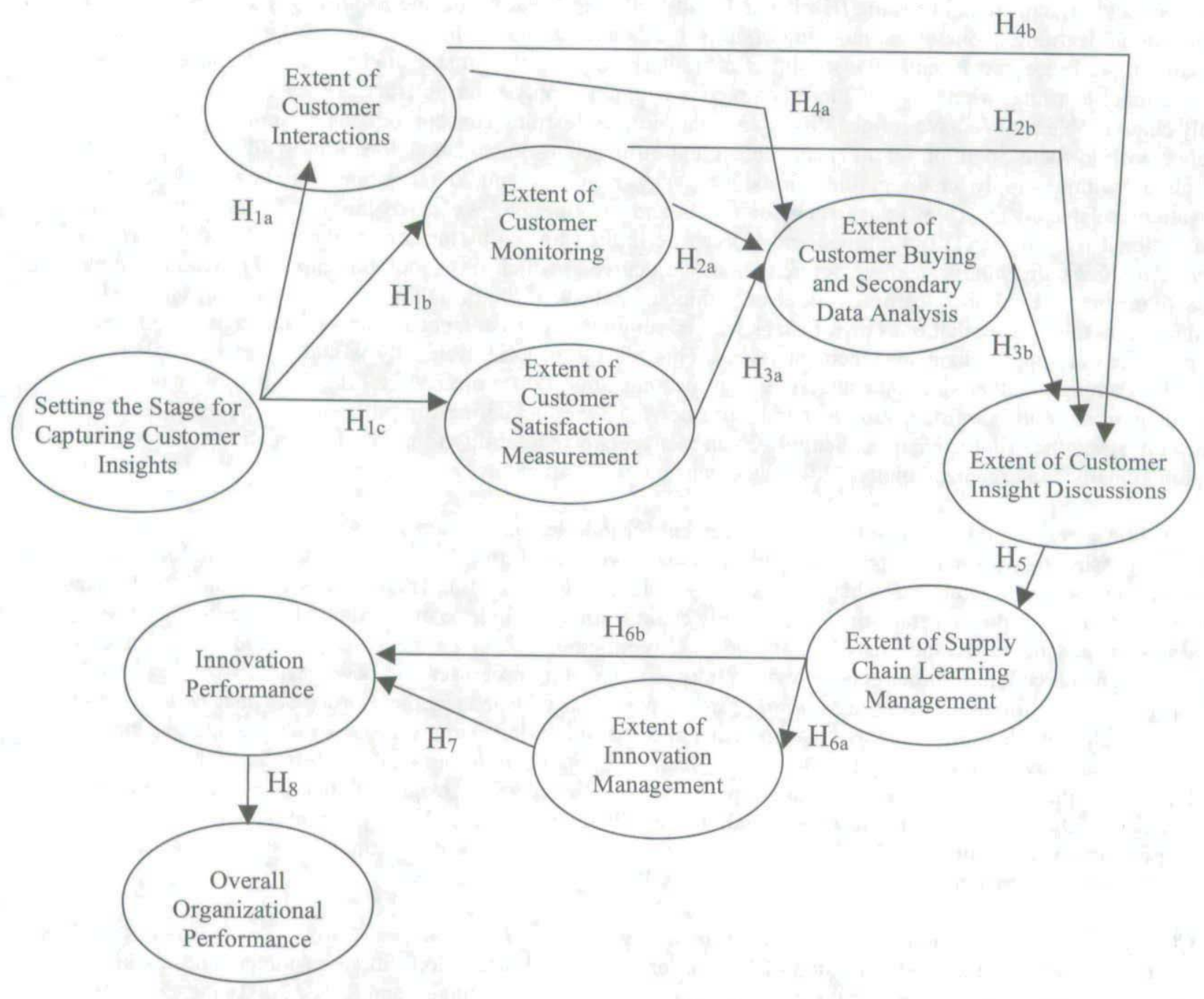




\section{Supply Chain Learning}

Firms that have a market orientation, meaning they have an attitude toward and processes aimed at, capturing customer and competitor data, sharing their insights throughout the firm, and responding to those insights, have been found to have superior market performance, including profitability (Jaworski and Kohli 1993; Matsuno, Mentzer, and Ozsomer 2002; Slater and Narver 2000). This sharing of market information is critical for collaboration, innovation and organizational learning (Hurley and Hult 1998; Jap 1999; Maltz and Kohli 1996). It is often said that organizational learning is one of the most important subjects to understand due to how critical it is for performance (Bessant 2004; Teece and Pisano 1994). Flint et al. (2005) extended this organizational learning concept to interorganizational learning, where two or more companies within a supply chain interact as they resolve logistics and supply chain problems. We have refined this inter-organizational learning concept to focus on supply chain learning. Here we wish to focus attention on the management and influence of organizational learning within one's own firm as well as within supply chain partner firms, both key suppliers and key customer organizations, targeting innovations related to the flow issues such for goods and information. We make this distinction because interorganizational learning is (1) quite broad and (2) can be limited to two partner organizations. Thus, the extent of supply chain learning management we define here as the degree to which firms look both up and down their supply chains to manage and monitor learning processes within and outside of the firm. For our purposes here, supply chain learning refers to ensuring that ones own firm as well as suppliers and customers are actively managing the learning process aimed at supply chain management issues. This may, and possibly ideally would, involve suppliers and customers coming together simultaneously in group meetings, but it does not have to. It is simply the management of learning across multiple firms, suppliers and customers, that we feel defines minimal supply chain learning. One of the core strengths of logisticians and supply chain managers is their ability to think in a boundary spanning way, both functionally and organizationally. This is an extension of that thinking.

It is, however, important to note that the requirement for joint learning processes as a supply chain management relationship issue suggests that the parties essentially must have mutual trust, be committed to long term cooperation and a willingness to integrate key business processes (Mentzer et al. 2001). This point is confirmed by Bessant (2004) who further proposes a stage model for supply chain learning leading to innovation. He suggests that a set-up stage should provide focus and shared motivation between supply chain partners. An operation stage involves agreements on shared goals and targets developed into new operating processes and new ways of working. In order to keep momentum for the process, a sustaining stage must deal with management processes that emphasize the needs for continuous learning such as measurements and benchmarking. Supply chain structures such as supplier associations may have a role to play at this stage. Comparing this model to our study, the driving force for further development is the customers' voice, or more specifically customer value insights, rather than measurement and benchmarking. Our model is, on the other hand, not explicitly addressing the implementation of supply chain learning and innovation into cross border operational procedures and processes, but merely assessing the extent of learning process management.

Clearly, managing dialogue between one's own organization and managers from supply chain partner organizations should be a natural extension of internal organizational discussions about customers and markets, as suggested by organizational learning research within logistics (Ellinger, Ellinger, and Keller 2002) and Figure 1. In most cases, extensive cross functional discussions about customers and how their demands are changing are likely to lead to the management of learning processes, both within one's own firm as well as at supplier and customer organizations because activities both up and down the supply chain affect processes within one's own firm. As managers attempt to modify their organization's products and services, they often must influence changes within supplier and customer organizations. The more these managers possess a learning orientation, the more likely they are to expect their supply chain partners to as well. The next hypothesis reflects this notion:

$\mathrm{H}_{5}$ : The greater the extent of customer insight discussions, the greater will be the extent of supply chain learning management.

\section{Innovation Management}

Innovation can occur within processes, products, services, organizational structures, management strategies and so on. It can be represented by continuous improvement or discontinuous and radical shifts in technology or ways of approaching a problem (Cooper 1999; Kahn 2001; Rogers 1995). Flint et al. (2005) suggest that logistics innovation 
can emerge out of the social process depicted in Figure 1. But clearly innovations do not need to emerge out of such a process. Numerous innovations have emerged from technological experimentation and serendipity. The issue is whether processes aimed at developing customer value insights and supply chain learning can lead to greater innovation efforts. We know what constitutes product development management and innovation management when we see it. It involves adopting formal processes such as the Stage Gate ${ }^{\circledR}$ product development process whereby new product ideas must pass through a series of gates toward development, market testing and launch. It involves active ideation (idea generation), numerous product development projects, formal monitoring of new product successes, and searches for technological transfer, to name a few tell tale signs (Kahn 2001). As such, we define the extent of innovation management as the degree to which organizations adopt standard formal processes for developing, launching, and monitoring the success of new products, services and solutions. Firms that adopt a strong customer orientation can be highly innovative with respect to market-directed new products and services (Cooper 1999). Similarly, firms engaged in active learning models, tend to also be more innovative (Bessant 2004).

\section{$\mathrm{H}_{6 \mathrm{a}}$ : The greater the extent of supply chain learning management, the greater will be the extent of} innovation management.

\section{Performance}

Most managers want to know if recommended processes impact organizational performance. Organizational performance can be measured in a multitude of ways, some objectively and some subjectively through managerial perceptions. There are also many variables that impact organizational performance. Given the nature of our study, we measured managerial perceptions of their organizations' performance regarding success of their innovations and overall performance including satisfaction of their customers. The more a firm engages in innovation management, the better ought to be innovation outputs (Kahn 2001). Additionally, the more a firm engages in learning processes, the better ought to be innovation outputs (Cooper 1999; Hurley and Hult 1998). As such, we hypothesize:

$\mathrm{H}_{7}$ : The greater the extent of innovation management, the better will be perceived innovation performance.

$\mathrm{H}_{6 \mathrm{~b}}$ : The greater the extent of supply chain learning management, the better will be perceived innovation performance.

Finally, improvement in innovation performance ought to positively affect overall performance and in particular customer satisfaction (Flint et al. 2005; Hurley and Hult 1998; Matsuno, Mentzer, and Ozsomer 2002). As such, we hypothesize: $\mathrm{H}_{8}$ : The better the perceived innovation performance, the better will be perceived overall organizational
performance.

The next sections describe the study designed to test these hypotheses.

\section{METHODOLOGY}

\section{Overview}

Our study was international in scope and cross-sectional survey based. We followed traditional survey development, scale purification, construct validity, and relational (i.e., correlational, structural equation modeling) procedures. The scales we used were largely developed based on literature conceptualizations and did not rely on pre-existing scales. As such this test is exploratory. That said, our factor analyses and subsequent statistical tests do reveal clear reliable and valid constructs that serve our test adequately.

\section{Operationalization}

We developed scales, i.e., sets of multiple questions designed to capture the domain of the constructs in question, to assess the extent to which respondents used certain activities that represented the domain of the concept. These scales are quite similar to numerous scales used in logistics research to test for the existence of business 
processes and tested through standard psychometric statistical analyses (Daugherty, Dröge, and Germain 1994; Daugherty, Myers, and Autry 1999; Germain, Dröge, and Spears 1996; Goldsby and Stank 2000; Narasimhan and Carter 1998; Stank and Lackey 1997). We drew from the literature as described in the previous literature review section to develop scales for each construct. We found that the scales we used for this test do reflect construct reliability and construct validity and as such can be dealt with as traditional reflective constructs. In an attempt to be parsimonious and increase the power of our study given our sample size, we refined each scale by removing those items that did not best fit each construct based on statistical grounds while ensuring that we retained the substantive meaning of each construct with retained items.

We developed ten scales for this study. The extent of setting the stage processes (STAGE) construct focused primarily on the extent to which managers were trained for capturing and analyzing customer value insights. The STAGE scale consisted of three questions. Recall that we divided the customer clue gathering step in Figure 1 into four constructs, i.e., extent of direct customer interaction (MEET), extent of customer market environment monitoring (MON), extent of customer satisfaction/complaint processes (SAT), and extent of customer buying and secondary data analysis (ANAL). The MEET scale meant the extent to which firms interact with customers in faceto-face meetings and was measured with four questions. The MON scale addressed the extent to which firms monitored customer relevant changes likely to affect what customers value and was measured with three questions. Monitoring is different from analyzing or meeting in that it is more akin to keeping an eye on the market via secondary means. The SAT scale addressed the existence of formal voice of the customer, satisfaction, and complaint systems as in customer satisfaction surveys. SAT was measured with three items. The ANAL scale measured the extent to which firms analyzed market and customer data and was measured with three questions.

The extent to which firms interpreted customer data and discussed it with internal groups was referred to as the extent of customer insight discussions (DISC) and was measured with three questions. The extent of supply chain learning management (LRN) scale addressed processes aimed at ensuring managers within one's own firm as well as customer organizations and supplier organizations were engaged in active learning management. It was measured with six questions. Innovation management (INN) referred to processes aimed at managing new product and service activities. It was measured with three questions. Innovation performance (PERFI) was measured with three questions and reflected managers' perceptions of the success of their new product and service innovations. Finally, the overall performance scale (PERFO) referred to managers' perceptions of their organization's overall performance, as partially measured by customer satisfaction and retention. It was measured with three questions. Many of the questions were randomized throughout the survey to help reduce common method biases.

Each of the 34 questions was asked as a Likert-like scale where respondents were asked to state the degree to which they agreed with specific statements on a 5-point dimensional range from strongly disagree (1) to strongly agree (5). See Appendix A for all scale questions.

\section{Sample}

The final survey, following a pre-test with 110 respondents, was mailed to senior marketing and sales executives and general managers at 3,400 firms in the United States, Sweden and Denmark. These countries although somewhat different on cultural dimensions, and size/scale of domestic organizations, are similar in their focus on innovation and process improvement. They also represent the locations of the managers who were participants in the original Flint et al. (2005) research, making them appropriate for a test of the model developed in that work. Preliminary discussions with business leaders revealed that these marketing/sales executives and managers would know best the extent to which their firm engaged in these activities even though we were addressing supply chain learning. Our interest was not to ask what logistics managers thought, but to gain the best insight to what organizations were doing with respect to issues with which logistics and supply chain managers ought to be interested.

Names, titles and addresses were obtained from regularly updated publicly available database sources. Funding was provided by several firms in the United States and Sweden. The 3,400 firms represent a random selection from 5,000 contacts, with one key contact per firm. We targeted manufacturing, logistics (e.g., third party logistics service providers, transportation, warehousing/distribution, rail, packaging, freight forwarding), consumer goods, retailing, health/medical and business services firms. 
As a benchmarking study, we wanted to explore these activities across a wide spectrum of industries. Most of the U.S. firms were Fortune 1000 companies. We received 322 useable surveys back, for a $9 \%$ response rate after two waves. Although the response rate is low, it is understandable given the high management level within large corporations at which we mailed the surveys, the length of the survey, and extent of survey burnout among business professionals. We did not provide an incentive to the sample, nor pre-qualify each of the participants via a call center, more costly techniques sometimes employed that could have enhanced our response rate. However, we did compare early and late respondents (Armstrong and Overton 1977) and contacted 10 non-respondents in the U.S. and found no meaningful, statistical differences in the means for the questions asked. As such, we are satisfied with the number we did receive for our given test, the variation within the questions, and the specific firms that responded. The response distribution was as follows: 117 from the United States, 157 from Sweden and 47 from Denmark. Response rates were similar from each country, with a slightly higher response rate from Sweden. This total sample size is adequate given the power needed to test the number of survey items we used and hypotheses we explored (Hair et al. 1995).

Demographics of respondents to the survey and their firms were what we expected with the possible exception of the slightly smaller size of the average business unit than we expected as depicted by annual revenues and number of employees. This is due primarily to $65 \%$ of the sample being represented by Scandinavian headquartered firms, typically smaller than their U.S. counterparts. Industries represented are shown in Table 1.

TABLE 1

STUDY SAMPLE

\begin{tabular}{|c|c|c|c|c|c|}
\hline Industry & Frequency & Percentage & Industry & Frequency & Percentage \\
\hline Consumer goods & 15 & $5 \%$ & Industrial Mfr & 152 & $47 \%$ \\
\hline Logistics services & 40 & $12 \%$ & Consumer services & 13 & $4 \%$ \\
\hline Other Business sve & 49 & $15 \%$ & Healthcare/medical & 19 & $6 \%$ \\
\hline Retailers & 11 & $3 \%$ & Food/beverage & 22 & $7 \%$ \\
\hline
\end{tabular}

\section{Measurement Analyses}

Measurement analyses refer to tests associated with ensuring that we measured what we set out to measure, i.e., construct validity. Construct validity must be determined prior to analyzing relationships among the constructs (Mentzer and Flint 1997). The items within scales, i.e., sets of questions designed to measure a construct, were examined for normality, skewness, and kurtosis prior to examining construct validity and reliability through standard approaches. Specifically, as per accepted statistical procedures for confirmatory factor analyses, we examined scale means, standard deviations, average variance extracted, highest shared variance with other constructs, modification indices, multi-collinearity, composite reliability via Cronbach's alpha, and overall measurement model fit indices via the statistical packages SPSS, LISREL and AMOS (Jöreskog and Sörbom 1996; Jöreskog et al. 1999). As a result of these analyses, we dropped a number of items that did not fit well. As shown in Table 2, the measurement results are adequate, with reliabilities for the constructs being generally good, all exceeding .70, considered the minimum value for acceptable construct reliability (Anderson and Gerbing 1991; Fornell and Larcker 1981). 
TABLE $2^{\text {a }}$

MEASUREMENT MODEL RESULTS

\begin{tabular}{|c|c|c|c|c|c|c|c|c|}
\hline & $\begin{array}{l}\text { Item } \\
\text { Mean }\end{array}$ & $\begin{array}{l}\text { Standard } \\
\text { Deviation }\end{array}$ & $\begin{array}{l}\text { Parameter } \\
\text { Estimate }\end{array}$ & $\begin{array}{l}\text { Scale } \\
\text { Mean }\end{array}$ & SD & $\begin{array}{c}\text { Scale } \\
\text { Cronbach's } \\
\text { Alpha }\end{array}$ & $\begin{array}{l}\text { Average } \\
\text { Variance } \\
\text { Extracted }\end{array}$ & $\begin{array}{l}\text { Highest } \\
\text { Shared } \\
\text { Variance }\end{array}$ \\
\hline Setting Stage & & & & 2.7 & .97 & .81 & $68 \%$ & $18 \%$ \\
\hline STAGE 1 & 2.9 & 1.1 & .688 & & & & & \\
\hline STAGE 2 & 2.7 & 1.0 & .758 & & & & & \\
\hline STAGE 3 & 2.5 & .90 & .726 & & & & & \\
\hline & & & & & & & & \\
\hline $\begin{array}{l}\text { Meeting with } \\
\text { Customers }\end{array}$ & $y_{1}$ & 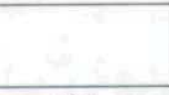 & & 3.2 & .90 & .71 & $64 \%$ & $8 \%$ \\
\hline MEET 1 & 3.4 & .95 & .725 & & & & & \\
\hline MEET 2 & 3.4 & .88 & .696 & & & & & \\
\hline MEET 3 & 3.1 & .67 & .631 & & & & & \\
\hline MEET 4 & 2.9 & .82 & .610 & & & & & \\
\hline & & & & & & & & \\
\hline $\begin{array}{l}\text { Monitor } \\
\text { Environment }\end{array}$ & & & & 3.1 & .85 & .75 & $62 \%$ & $24 \%$ \\
\hline MON 1 & 3.5 & .84 & .695 & & & & & \\
\hline MON 2 & 2.7 & 1.2 & .702 & & & & & \\
\hline MON 3 & 3.2 & .95 & .700 & & & - & & \\
\hline & 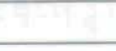 & 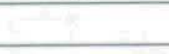 & & & & & +2 & \\
\hline $\begin{array}{l}\text { Formal } \\
\text { Satisfaction } \\
\text { Processes }\end{array}$ & 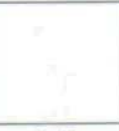 & 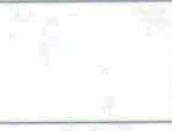 & & 3.9 & .81 & .72 & $63 \%$ & $20 \%$ \\
\hline SAT 1 & 3.7 & 1.0 & .675 & & & & & \\
\hline SAT 2 & 3.9 & 1.0 & .843 & & & . & +2 & \\
\hline SAT 3 & 4.2 & .85 & .803 & & & & 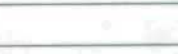 & \\
\hline & & & & & & & & 2401 \\
\hline Analyze Data & & & & 3.7 & .83 & .78 & $63 \%$ & $24 \%$ \\
\hline ANAL 1 & 4.0 & .79 & .703 & & & & & \\
\hline ANAL 2 & 3.9 & .67 & .681 & & & & +2 & + \\
\hline ANAL 3 & 3.3 & 1.1 & .762 & & & & +2 & +2 \\
\hline 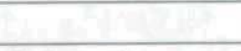 & & +2 & +2 & & & + & + & 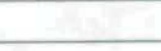 \\
\hline $\begin{array}{l}\text { Internal } \\
\text { Discussions }\end{array}$ & & +2 & & 3.5 & .79 & .80 & $64 \%$ & $32 \%$ \\
\hline DISC 1 & 3.8 & .88 & .672 & & & & & \\
\hline DISC 2 & 3.5 & 1.0 & .733 & & & & & \\
\hline DISC 3 & 3.3 & .98 & .716 & & & & & \\
\hline & 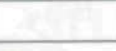 & +2 & +2 & & & & & \\
\hline $\begin{array}{l}\text { Supply Chain } \\
\text { Learning }\end{array}$ & & 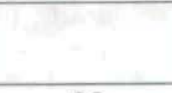 & & 3.6 & .63 & .80 & $64 \%$ & $23 \%$ \\
\hline LRN 1 & 3.8 & .88 & .747 & & & & & \\
\hline LRN 2 & 3.6 & 1.2 & .677 & & & & & \\
\hline LRN 3 & 3.5 & 1.0 & .637 & & & & & \\
\hline LRN 4 & 3.5 & 1.0 & .675 & & & & & \\
\hline LRN 5 & 3.6 & .93 & .709 & & & & & \\
\hline LRN 6 & 3.7 & .88 & .679 & & & & & \\
\hline & & & & & & & & \\
\hline
\end{tabular}


TABLE $2^{\mathrm{a}}$ (continued)

\begin{tabular}{|l|l|l|l|l|l|l|l|l|}
\hline $\begin{array}{l}\text { Innovation } \\
\text { Management }\end{array}$ & & & & 3.6 & .99 & .85 & $66 \%$ & $21 \%$ \\
\hline INN 1 & 3.8 & 1.2 & .764 & & & & & \\
\hline INN 2 & 3.5 & 1.2 & .835 & & & & & \\
\hline INN 3 & 3.3 & 1.2 & .771 & & & & & \\
\hline & & & & & & & $65 \%$ & $21 \%$ \\
\hline $\begin{array}{l}\text { Innovation } \\
\text { Performance }\end{array}$ & & & & & & & .74 & \\
\hline PERFI 1 & 3.4 & .85 & .728 & & & & & \\
\hline PERFI 2 & 3.3 & 1.0 & .697 & & & & & \\
\hline PERFI 3 & 3.3 & .99 & .673 & & & & & \\
\hline & & & & & & & & \\
\hline $\begin{array}{l}\text { Overall } \\
\text { Performance }\end{array}$ & 3.7 & .85 & .600 & & & & & \\
\hline PERFO 1 & 3.9 & .74 & .721 & & & & & \\
\hline PERFO 2 & 3.9 & .69 & .656 & & & & & \\
\hline PERFO 3 & & & & & & & & \\
\hline
\end{tabular}

"Note: measurement model fit statistics: $\chi^{2}=921.5, \mathrm{df}=492$, CFI .92 , Delta 2.92 , RMSEA .052

Discriminant validity was established by calculating the shared variance between all possible pairs of constructs and verifying that they were lower than the average variance extracted for the individual constructs (Fornell and Larcker 1981; Jöreskog et al. 1999). All constructs extracted average variances exceeding .50 and had average extracted variances greater than the highest shared variance between the focal construct and any other construct in the model (see Table 2),

The measurement model fit was evaluated using the comparative fit index (CFI), relative noncentrality index (RNI), and DELTA2 index and seeking a chi-square to degrees of freedom ratio of about $2: 1$. These fit indices have been shown as the most stable fit indices in LISREL models by Anderson and Gerbing (1991). Fit results (i.e., $\mathrm{CFI}=.92$, RNI $=.92$, DELTA $2=.92$ ) which should be greater than .90 in combination with Chi-square given degrees of freedom $\left(\chi^{2}=921.5, \mathrm{df}=492\right.$ for a ratio of $\left.1.87: 1\right)$, RMSEA $(.052)$, reliability, and variance results suggest the measurement scales are reliable and valid for this study.

With all of our survey items worded positively (i.e., no reverse coding) and all hypotheses stated in the positive direction, common method bias might affect our results. The common method bias issue in self-report survey research and ways of addressing it have been discussed elsewhere (Lindell and Whitney 2001; Menon, Bharadwaj, and Howell 1996; Podsakoff and Organ 1986; Podsakoff et al. 2003). Addressing the problem of artificial covariance due to common method can be accomplished both within survey design and post-hoc analysis. For example, in survey design, one might randomize items such that all scale items are not always grouped together. Additionally, researchers can include a marker variable that should not be theoretically related to at least one and ideally most of the variables in the model being tested, and/or use second(ary) data sources for some of the variables being examined. Post-hoc, researchers can conduct the Harmon one factor test. If there is a common method bias, a single factor model should also fit the data well. The single factor measurement model results should represent a worse fit than the confirmatory factor analysis measurement results in such a test if there is not a common method bias.

In this study, we randomized many of the construct items and conducted a post hoc analysis for common method bias using the Harmon one factor test of all the items for our constructs and sub-sets of them, as suggested by Menon, Bharadwaj, and Howell (1996). We did not include a marker variable nor collect data from more than one source. This test showed that single factor models had much poorer fit to the data than the measurement model we proposed. This, combined with heuristic observation of the variation across item responses within and across surveys, supports our claim to not have a common method bias problem. 


\section{FINDINGS}

Upon establishing construct validity, we examined the scale means to make broad statements about the extent to which organizations did indeed utilize the measured processes, i.e., our first research objective. Our conclusions are that across the entire sample, firms were stronger, as reflected in scale means, in their use of processes for analyzing customer data, holding internal discussions about customers, and managing innovation activities. Sample firms are weaker in their use of processes aimed at setting a stage for customer listening, i.e., training managers to look for clues to changes in what customer value.

We then examined the correlation between each construct and all other constructs. The primary assertion of the literature is that these activities ought to be correlated. The correlation matrix for all of the constructs in our model is provided in Table 3. All reported correlations are statistically significant at the $\mathrm{p} \leq .01$ level.

TABLE $3^{\text {a }}$

\section{CORRELATION MATRIX OF CONSTRUCTS}

\begin{tabular}{|l|c|c|c|c|c|c|c|c|c|c|}
\hline & STAGE & MEET & MON & SAT & ANAL & DISC & LRN & INN & PERFI & PERFO \\
\hline STAGE & 1.0 & & & & & & & & & \\
\hline MEET & .280 & 1.0 & & & & & & & & \\
\hline MON & .310 & .210 & 1.0 & & & & & & & \\
\hline SAT & .420 & .231 & .340 & 1.0 & & & & & & \\
\hline ANAL & .271 & $.118^{* *}$ & .488 & .355 & 1.0 & & & & & \\
\hline DISC & .369 & .251 & .457 & .430 & .426 & 1.0 & & & & \\
\hline LRN & .347 & .237 & .476 & .444 & .445 & .568 & 1.0 & & & \\
\hline INN & .185 & $.093^{* *}$ & .424 & .292 & .304 & .250 & .336 & 1.0 & & \\
\hline PERFI & .260 & .123 & .309 & .281 & .281 & .269 & .327 & .454 & 1.0 & \\
\hline PERFO & $.133^{*}$ & .232 & $.128^{*}$ & .179 & .135 & .174 & .225 & .224 & .359 & 1.0 \\
\hline
\end{tabular}

Notes:

$*$ significant at $\mathrm{p} \leq .05$

$* *$ significant at $\mathrm{p} \leq .10$

All others significant at $\mathrm{p} \leq .001$

Overall, the correlations suggest that all constructs (i.e., sets of activities) are related and important to supply chain learning, innovation and performance. This confirms findings from the literature.

\section{Industry and Country Comparisons}

We then compared the data along both industry and country dimensions. Mean scores for retailers, consumer services, health care, and food/beverage companies were higher than the other industries on setting the stage activities. It could be that consumer oriented firms have such strong traditions of market data collection and analyses that they tend to lay the groundwork for formal market sensing activities more than firms in other industries. Mean scores were similar across industries for meeting customers, analyzing customer data, and monitoring the environment scales. However, retailers scored lower on meeting with customers. This might be explained due to the vast number of consumers who retailers consider "customers" and the unlikelihood of retailers engaging in the formal group face-to-face meeting activities we measured. The mean score for analyzing customer and market data for industrial manufacturers was low as compared to other industries. This fits with our own experience that industrial firms tend to be less formal and systematic about capturing and analyzing customer data. Logistics service providers and healthcare/medical industries scored lowest on monitoring the market environment. Retailers by far exceeded other industries in terms of discussing voice of the customer data and supply chain learning activities. Consumer goods, retailers and food/beverage firms' mean scores for innovation activities were higher than those of firms in the other industries. These findings might help managers in looking for benchmarking opportunities on specific kinds of processes. 
With respect to country comparisons, there were not any statistically significant differences between countries, thus enabling us to pool the data. However, mean scores for face-to-face meetings with customers were slightly higher for Denmark and Sweden samples than that of the United States. There could be a cultural explanation for this difference pointing out that Scandinavian firms are more likely to interact on a social and informal basis with customers and suppliers (Håkansson and Snehota 1986/2006) than are their American counterparts. According to the model, this result indicates that Scandinavian firms with their network approach may have a competitive advantage in that respect when it comes to customer value insights.

We then proceeded to test hypothesized relationships through structural equation modeling.

\section{Structural Analysis}

To explore the relationships among the constructs, we examined the data via the model presented in Figure 2. We tested this model by entering the item correlation matrix into the statistical packages LISREL and AMOS (to check for consistency of results, which we did) in order to run structural equation modeling. These analyses found support for 13 of 14 hypotheses. Hypothesis $\mathrm{H}_{4 a}$, suggesting greater data analysis for firms with higher levels of direct customer interactions was not supported. This could mean that simply meeting with customers does not necessarily mean organizations spend time later in subsequent data analyses. In fact, many organizations may meet with customers but not formally collect much data, using those meetings more as a relationship building exercise.

The fit statistics for the structural model were acceptable (i.e., CFI .90, DELTA 2 .90, Chi-square/degrees of freedom $913.232 / 515$ or ratio 1.7/1, RMSEA .049). The parameter estimates are shown in Figure 3.

The first observation is that the general flow of the originally proposed framework was supported. Specifically, the extent to which a firm sets a stage for capturing and analyzing customer data does contribute to increased customer data collection and analyses. Similarly, the greater the extent of analyzing customer data, the greater the extent a firm will engage in discussions about customers. The more a firm engages in these discussions, the greater the extent of its supply chain learning management. Finally, the greater the extent of supply chain learning management processes, the greater the extent of innovation management, and then eventually performance. To summarize, the more firms engage in the preliminary processes, the more likely they are to actively manage supply chain learning and innovation. Stated another way, capturing customer value insights and actively discussing these insights across functional boundaries encourages firms to ensure that they and their supply chain partners are actively using this learning to improve how they serve each other and develop innovations. 
FIGURE $3^{\text {a }}$

STRUCTURAL EQUATION MODEL RESULTS FOR TEST OF HYPOTHESIZED MODEL

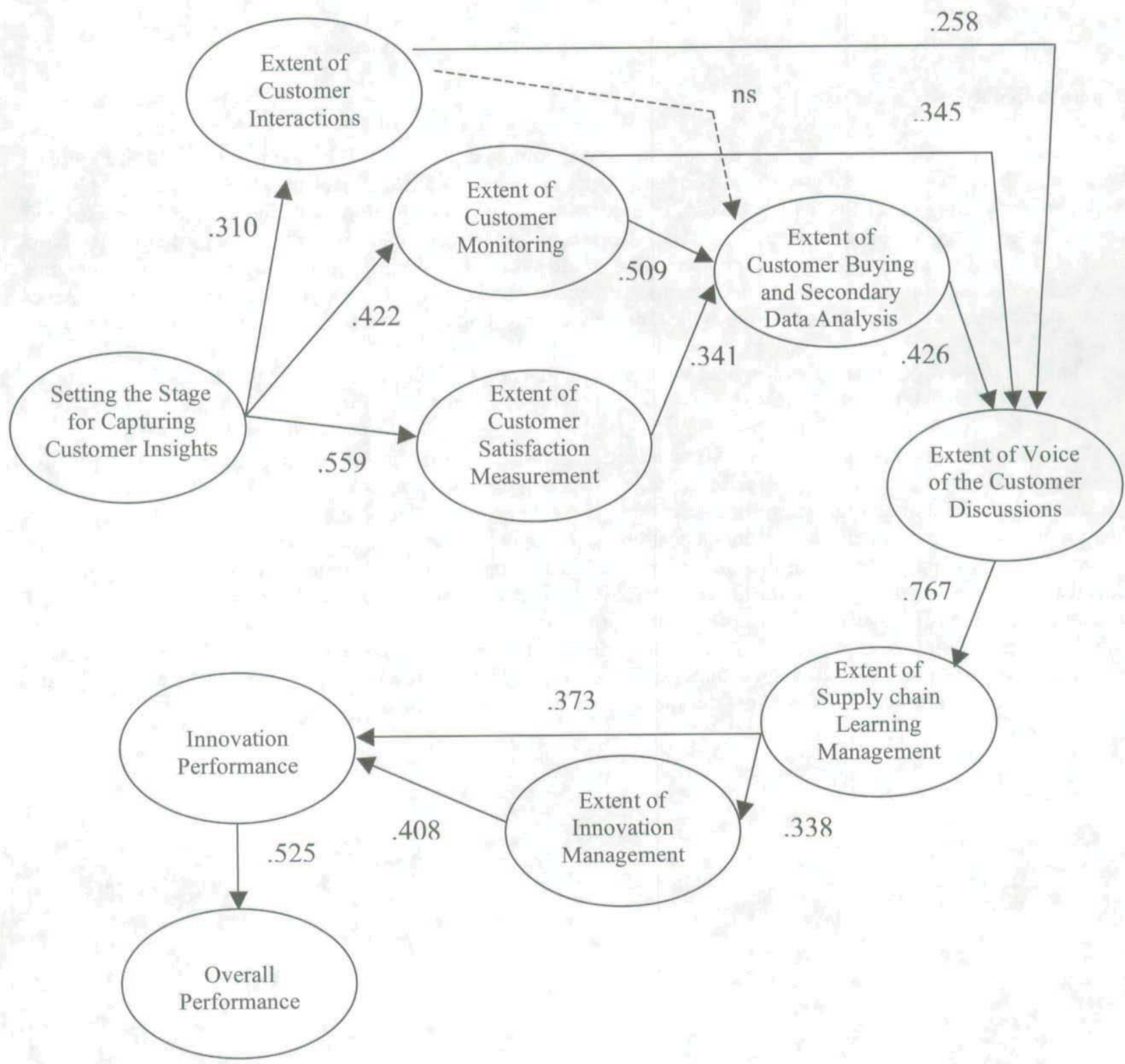

a) Notes:

All significant paths significant at the $\mathrm{p} \leq .01$ level or better $\mathrm{ns}=$ not significant

Fit statistics:

$\chi^{2}=913.232, \mathrm{df}=515, \mathrm{CFI}=.90$, Delta $2=.90, \mathrm{RMSEA}=.049$ 


\section{DISCUSSION}

We feel that this research has both managerial and research implications, even given its limitations. As we stated, this study is limited in a number of ways. First, the scales and hypotheses were exploratory. There is not a plethora of significant antecedent literature justification for the model, although individual components do have support as we showed. Additionally, we did not engage in a full scale development study using multiple methods and samples, something that ought to be done to improve the measurement of the constructs operationalized here. Third, the sample size is marginal given the size of the population whose behavior we wish to explain. For enhanced generalizabiliy, additional studies with large samples ought to be executed. Fourth, the fit statistics are acceptable but not outstanding. We feel that this is due in large part to the strength of the individual scales and not the theoretical model itself. Future research should reduce these limitations.

\section{Managerial Implications}

Our aim was to determine the extent to which firms relied on processes for capturing customer value insights to drive supply chain learning and innovation, i.e., to benchmark firms engaged in such activities. Given that none of the scale means for any of the constructs was toward the high end (e.g., 4 or 5), we can interpret that most firms in our sample do not engage in these processes to the extent that they think they could (otherwise they would have scored more items as "strongly agree" or 5). Given the strength of the relationships among the constructs though, managers ought to think about the extent to which their firms are engaged in each of the processes measured here. Supply chain managers and logistics managers might want to find ways to contribute toward processes at each stage of the model. The next paragraphs explain specifically what we mean.

Begin with setting the stage processes. Supply chain and logistics managers might consider how well trained they and their subordinates are at using tools and techniques for capturing and analyzing customer data. Our experience shows that many of these managers have a solid understanding of operationally focused statistics inherent in operations research, lean manufacturing and "Six Sigma" initiatives. Yet, few are proficient in studying the behaviors of people in a psychographic and social sense, a skill often relegated to marketing and sales professionals. Insights of this type are clearly relevant to what supply chain and logistics managers must do if they are to develop innovative solutions to customers' problems or support launches of innovative products to those customers. Additionally, since so many supply chain and logistics managers spend time as boundary spanners serving many internal and external customers, being well versed on ways to study the behaviors, attitudes and opinions of those "customers" might strengthen relationships. It is amazing how often we see relationship management facilitate or detract from operational success. It may be that additional training is required in the areas of observing, interviewing, and surveying people's behaviors, attitudes and opinions. Subjective or not, attitudes and opinions impact customers' decision making. Beyond this, managers might consider additional ways to get in front of customers such as becoming more involved in cross functional account management teams if they are not already. Firms like Nestlé, Sony and Norfolk Southern have such cross functional account management teams that include supply chain experts.

Continuing on with the model, we can not emphasize enough the seemingly subtle difference between collecting data on what customers currently value or even satisfaction with past performance and data that will help managers anticipate what customers will or might value in the future. The latter looks at changes in what is valued over time and leading indicators of changes in what is valued such as changes in customers' organizational structure, key personnel, key processes, and strategies. Many of our survey questions focused on customer insights oriented toward changes taking place, not merely what is currently valued. Some customer-related changes may influence sourcing of supply chain operations as well as expectations of logistics services. This way of viewing the market looks at changes in the economic and regulatory environment, changes in relevant technology, mergers or acquisitions within supply chains and so on. This requires a different eye toward the marketplace and supply chain. Supply chain managers and logistics managers see supply chain and operations problems differently than do marketers or sales professionals. Their insights to and interactions with customers are needed because processes will be improved in the long run that benefit both customers and supplying firms. It is often advantageous for supply chain and logistic managers to obtain information related to product and service development directly from the source in addition to information they obtain from sales and marketing. 
Most successful organizations have internal discussions about customers. The degree to which supply chain and logistics managers are involved in them at an early stage so as to assist in more holistic interpretations of trends and what customers are likely to value in the future is questionable. Supply chain and logistics managers might want to consider how involved they want to be in these discussions and at what point. The last thing any manager needs is another meeting. However, not being involved early may mean being required to respond with packaging, inventory, or transportation solutions that are less than optimal.

Supply chain learning as addressed here refers to multiple supply chain partners engaged in interaction where learning occurs and is focused on supply chain issues and solutions. It refers to ensuring that organizations including suppliers and customers are constantly vigilant to learning opportunities as reflected by attitudes and behaviors. In particular, it refers to engaging in dialogue with suppliers and customers focused on better ways to serve each other. This may involve product modifications, entirely new products, or supply chain modifications such as network redesign, transportation route and mode modeling, package design, information systems modifications, enhancing goods in transit visibility through the application of emergent technologies or improving forecasting accuracy to name a few areas on which supply chain managers traditionally focus. Our focus here is on the management of learning processes that result in innovations in any of these areas. Supply chain managers and logistics managers might want to consider the extent to which they actively manage or try to influence cross-organizational learning, ensuring that their employees and other managers are altering their attitudes and behaviors based on lessons learned and opportunities uncovered from these cross-organizational interactions.

Finally, we address innovation. Many fast moving consumer goods (FMCG) and durable consumer goods firms in general are well versed in managing new product development and customer oriented innovation within their organizations. Similarly, supply chain managers and logistics managers within OEMs and logistics service provider firms have developed numerous innovations in tools, services, and processes that have improved the efficiency and/or effectiveness of serving supply chain needs. However, we urge these supply chain managers to also take a serious look at their own firm's formal innovation management processes. To what extent are standard, accepted and time-tested processes being used to develop and manage innovative products and services? How many new product or service ideas are explored and at what level of rigor? What gates are these ideas required to pass through before making their way to launch? What metrics are used to determine success or failure of new product and service launches? Are these same practices applied to supply chain and logistics innovations? Do managers actually know what constitutes an innovation in supply chain management and the impact of those innovations? Supply chain and logistics managers have a voice in these processes. And more to our model, the more the previous processes are adopted, the more likely innovation processes will be managed well also. Formal cross-functional and crossorganizational management of these processes seems to be key to developing innovations that customers will value be they supply chain or product innovations. Our study suggests that all of these processes contribute to successful innovations and overall organizational performance.

\section{Research Implications}

From a scholastic point of view, this research is exploratory, yet suggests some areas for future research. In an age of extensive structural equation modeling, "state of the art" or "benchmarking" forms of research are not often found. However, it is critical for us to know the extent to which firms are actually adopting the processes researchers recommend. We have provided some insight there. Future research needs to continue to expand our understanding of innovation within a supply chain context. We see this as involving both examples of supply chain innovations and the processes used to arrive at them as well as supply chain managers' roles within new product development and management. We need to continue to explore how firms can better anticipate or at least recognize emergent supply chain opportunities with enough lead time to develop sustainable and scalable innovations. To this end, we need to know more about the best ways of tracking data on leading indicators of change that logistics and supply chain managers can best obtain, such as relevant technological advances, organizational changes within third party logistics organizations, relevant supplier related changes and so forth.

Additionally, supply chain learning is an area wide open for future research. What are the best ways of managing supply chain learning while maintaining control of proprietary information and relationships with multiple supply chain partners who may be competitors themselves? Who should be involved and at what time in learning exercises? What are the best ways to motivate a continuous and healthy supply chain learning environment? We do not feel these questions have been adequately addressed to date. The insights we have provided here we hope provide a contribution to the discourse on the topic of supply chain learning and innovation. 


\section{NOTES}

Anderson, James C. and David W. Gerbing (1991), "Predicting the Performance of Measures in a Confirmatory Factor Analysis with a Pretest Assessment of Their Substantive Validities," Journal of Applied Psychology, Vol. 76, No. 5 , pp. 732-740.

Armstrong, J. Scott and Terry S. Overton (1977), "Estimating Non-Response Bias in Mailing Surveys," Journal of Marketing Research, Vol. 14, No. 3, pp. 396-402.

Bessant, John (2004), "Supply Chain Learning," in Understanding Supply Chains. Concepts, Critiques and Futures, New, Steve and Roy Westbrook (eds.), Oxford: Oxford University Press, pp. 165-190.

Beverland, Michael, Francis Farrelly, and Zeb Woodhatch (2004), "The Role of Value Change Management in Relationship Dissolution: Hygiene and Motivational Factors," Journal of Marketing Management, Vol. 20, pp. 927939.

Beverland, Michael and Larry Lockshin (2003), “A Longitudinal Study of Customers' Desired Value Change in Business-to-Business Markets,” Industrial Marketing Management, Vol. 32, No. 8, pp. 653-666.

Cooper, Robert G. (1999), "From Experience: The Invisible Success Factors in Product Innovation," Journal of Product Innovation Management, Vol. 16, No. 2, pp. 115-33.

Daugherty, Patricia J., Cornelia Dröge, and Richard Germain (1994), "Benchmarking Logistics in Manufacturing Firms,” The International Journal of Logistics Management, Vol. 5, No. 1, pp. 9-18.

Daugherty, Patricia J., Matthew B. Meyers, and Chad W. Autry (1999), “Automatic Replenishment Programs: An Empirical Examination,” Journal of Business Logistics, Vol. 20, No. 2, pp. 63-82.

Day, George S. (1994), "The Capabilities of Market Driven Organizations," Journal of Marketing, Vol. 58, No. 4, pp. 37-52.

Dröge, Cornelia, Jayanth Jayaram, and Shawnee K. Vickery, (2000), "The Ability to Minimize the Timing of New Product Development and Introduction: An Examination of Antecedent Factors in the North American Automobile Supplier Industry,” Journal of Product Innovation Management, Vol. 17, No. 1, pp. 24-40.

Ellinger, Alexander, Andrea D. Ellinger, and Scott B. Keller (2002), "Logistics Managers' Learning Environments and Firm Performance," Journal of Business Logistics, Vol. 23, No. 1, pp. 19-37.

ELA (European Logistics Association)/A.T. Kearney Management Consultants (2004), Differentiation for Performance Excellence in Logistics 2004.

Fawcett, Stanley E., Sheldon R. Smith, and M. Bixby Cooper (1997), "Strategic Intent, Measurement, Capability, and Operation of Success: Making the Connection," International Journal of Physical Distribution and Logistics Management, Vol. 27, No. 7, pp. 410-421.

Flint, Daniel J., Everth Larsson, Britta Gammelgaard, and John T. Mentzer (2005), "Logistics Innovation: A Customer Value-Oriented Social Process,” Journal of Business Logistics, Vol. 26, No. 1, pp. 113-147.

Fornell, Claes and David F. Larcker (1981), "Evaluating Structural Equation Models with Unobservable Variables and Measurement Error,” Journal of Marketing Research, Vol. 18, No. 1, pp. 39-50.

Gale, Bradely T. (1994), Managing Customer Value, New York: Free Press.

Germain, Richard, Cornelia Dröge, and Nancy Spears (1996), "The Implications of Just-In-Time for Logistics Organization Management Performance," Journal of Business Logistics, Vol. 17, No. 2, pp. 19-34. 
Goldsby, Thomas J. and Theodore P. Stank (2000), "World Class Logistics Performance and Environmentally Responsible Logistics Practices,” Journal of Business Logistics, Vol. 21, No. 2, pp. 187-208.

Griffin, Abbie (1997a), "The Effect of Project and Process Characteristics on Product Development Cycle Time," Journal of Marketing Research, Vol. 34, No. 1, pp. 24-35.

Griffin, Abbie (1997b), "PDMA Research on New Product Development Practices: Updating Trends and Benchmarking Best Practices," Journal of Product Innovation Management, Vol. 14, No. 6, pp. 429-458.

Gulati, Ranjay and James B. Oldroyd (2005), "The Quest for Customer Focus," Harvard Business Review, Vol. 83, No. 4 (April), pp. 92-101.

Gupta, Anil K. and Vijay Govindarajan (2000), "Knowledge Flows within Multinational Corporations," Strategic Management Journal, Vol. 21, No. 4, pp. 473-497.

Hair, Joseph F., Jr., Rolph E. Anderson, Ronald L. Tatham, and William C. Black (1995), Multivariate Data Analysis, $4^{\text {th }}$ ed., Upper Saddle River, NJ: Prentice Hall.

Håkansson, Håkan and Ivan Snehota (1989), "No Business is an Island: The Network Concept of Business Strategy," Scandinavian Journal of Management, Vol. 5, No. 5, pp. 187-200 (reprinted in the same journal in 2006, Vol. 22, No. 3, pp. 256-270).

Hamel, Gary and C. K. Prahalad (1994), Competing for the Future, Boston, MA: Harvard Business School Press.

Hammer, Michael (2001), The Agenda - What Every Business Must Do to Dominate the Decade, New York: Crown Business.

Hult, G. Tomas M., Daid J. Ketchen, S. Tamer Cavusgil, and Roger J. Calantone (2006), "Knowledge as a Strategic Resource in Supply Chains," Journal of Operations Management, Vol. 24, No. 5, pp. 458-475.

Hurley, Robert F. and G. Tomas M. Hult (1998), "Innovation, Market Orientation, and Organizational Learning: An Integration and Empirical Examination," Journal of Marketing, Vol. 62, No. 3, pp. 42-54.

Jap, Sandy D. (1999), "Pie-Expansion Efforts: Collaboration Processes in Buyer-Seller Relationships," Journal of Marketing Research, Vol. 36, No. 4, pp. 461-475.

Jaworski, Bernard J. and Ajay K. Kohli (1993), "Market Orientation: Antecedents and Consequences," Journal of Marketing, Vol. 57, No. 3, pp. 53-70.

Jöreskog, Karl G. and Dag Sörbom (1996), LISREL 8: User's Reference Guide. Chicago, IL: Scientific Software International, Inc.

Jöreskog, Karl G., Dag Sörbom, Stephen Du Toit, S., and Mathilda Du Toit (1999), LISREL 8: New Statistical Features, Chicago, IL: Scientific Software International, Inc.

Kahn, Kenneth B. (2001), Product Planning Essentials, Thousand Oaks, CA: Sage Publications, Inc.

Kelley, Thomas and Jonathan Littman (2005), Ten Faces of Innovation, New York: Currency Doubleday.

Lane, Peter J. and Michael Lubatkin (1998), "Relative Absorptive Capacity and Inter-organizational Learning," Strategic Management Journal, Vol. 19, No. 5, pp. 461-478.

Larsson, Everth N. S. and Anders Ljungberg (2007), "Process Orientation," chapter seven in Handbook of Global Supply Chain Management, eds. John T. Mentzer, Theodore P. Stank, and Matthew B. Myers, Thousand Oaks, CA: Sage Publications, Inc. 
Lindell, Michael K. and David J. Whitney (2001), “Accounting for Common Method Variance in Cross-Sectional Research Designs,” Journal of Applied Psychology, Vol. 86, No. 1, pp. 114-121.

Maltz, Eliot and Ajay K. Kohli (1996), "Market Intelligence Dissemination across Functional Boundaries," Journal of Marketing Research, Vol. 33, No. 1, pp. 47-61.

Matsuno, Ken, John T. Mentzer, and Aysegul Ozsomer (2002), "The Effects of Entrepreneurial Proclivity and Market Orientation on Business Performance," Journal of Marketing, Vol. 66, No. 3, pp. 18-32.

Menon, Anil, Sundar G. Bharadwaj, and Roy Howell (1996), "The Quality and Effectiveness of Marketing Strategy: Effects of Functional and Dysfunctional Conflict in Interorganziational Relationships," Journal of the Academy of Marketing Science, Vol. 24, No. 4, pp. 299-313.

Mentzer, John T., William DeWitt, James S. Keebler, Soonhong Min, Nancy W. Nix, Carlo D. Smith, and Zach G Zacharia (2001), "Defining Supply Chain Management," Journal of Business Logistics, Vol. 22, No. 2, pp. 1-25.

Mentzer, John T. and Daniel J. Flint (1997), "Validity in Logistics Research," Journal of Business Logistics, Vol. 18, No. 1, pp. 199-216.

Mentzer, John T., Daniel J. Flint, and G. Tomas M. Hult, (2001) "Logistics Service Quality as a SegmentCustomized Process," Journal of Marketing, Vol. 65, No. 4, pp. 82-104.

Moorman, Christine and Rebecca J. Slotegraaf (1999), "The Contingency Value of Complementary Capabilities in Product Development," Journal of Marketing Research, Vol. 36, No. 2, pp. 239-57.

Narasimhan, Ram and Joseph R. Carter (1998), "Linking Business Unit and Material Sourcing Strategies," Journal of Business Logistics, Vol. 19, No. 2, pp. 155-171.

Narver, John C., Stanley F. Slater and Douglas L. MacLachlan (2004), "Responsive and Proactive Market Orientation and New-Product Success," Journal of Product Innovation Management, Vol. 21, No. 5, pp. 334-347.

Podsakoff, Philip M. and Dennis W. Organ (1986), "Self-Reports in Organizational Research: Problems and Prospects," Journal of Management, Vol. 12, No. 4, pp. 531-544.

Podsakoff, Philip M., Scott B. Mackenzie, Jeong-Yeon Lee, and Nathan P. Podsakoff (2003), "Common Method Biases in Behavioral Research: A Critical Review of the Literature and Recommended Remedies," Journal of Applied Psychology, Vol. 88, No. 5, pp. 879-903.

Popcorn, Faith (1991), The Popcorn Report, New York: Harper Business.

Quinn, Francis J. (2001), "A New Agenda for the Decade: An Interview with Michael Hammer," Supply Chain Management Review, Vol. 5, No. 6, pp. 36-40. Reichheld, Frederick F. (1996), The Loyalty Effect: The Hidden Force Behind Growth, Profits, and Lasting Value
Boston, MA: Harvard Business School Press.

Rogers, Everett M. (1995), Diffusion of Innovations, $4^{\text {th }}$ ed., New York: Free Press.

Scannell, Thomas V., Shawnee K. Vickery, and Cornelia L. Dröge (2000), "Upstream Supply Chain Management and Competitive Performance in the Automotive Supply Industry," Journal of Business Logistics, Vol. 21, No. 2, pp. Shrivastava, Paul (1983), “A Typology of Organizational Learning Systems,” Journal of Management Studies, Vol.
20, No. 1, pp. 7-28.

Slater, Stanley and John C. Narver (2000), "Intelligence Generation and Superior Customer Value," Journal of the Academy of Marketing Science, Vol. 28, No. 1, pp. 120-127. 
Stank, Theodore P. and Charles W. Lackey, Jr. (1997), "Enhancing Performance through Logistical Capabilities in Mexican Maquiladora Firms,” Journal of Business Logistics, Vol. 18, No. 1, pp. 91-123.

Teece, D. and G. Pisano (1994), "The Dynamic Capabilities of Firms: An Introduction," Industrial and Corporate Change, Vol. 3, No. 3, pp. 537-556.

Woodruff, Robert B. and Sarah Fisher Gardial (1996), Know Your Customer: New Approaches to Customer Value and Satisfaction, Cambridge, MA: Blackwell Publishers.

Zacharia, Zach G. and John T. Mentzer (2004), "Logistics Salience in a Changing Environment," Journal of Business Logistics, Vol. 25, No. 1, pp. 187-210. 


\section{APPENDIX A \\ SURVEY QUESTIONS}

Note: Each statement was scored by respondents on a Likert-like scale, ranging from Strongly Disagree (value of 1 ) to Strongly Agree (value of 5)

\begin{tabular}{|c|c|}
\hline \multicolumn{2}{|r|}{ We formally train same of aum neonla in cy } \\
\hline STAGE 1 & $\begin{array}{l}\text { We formally train some of our people in customer satisfaction measurement and analysis } \\
\text { techniques. }\end{array}$ \\
\hline STAGE 2 & We formally train some of our people in facilitating group customer meetings. \\
\hline STAGE 3 & $\begin{array}{l}\text { We formally train some of our people in conducting and analyzing open-ended depth } \\
\text { interviews. }\end{array}$ \\
\hline \multicolumn{2}{|l|}{$\begin{array}{l}\text { Meeting with } \\
\text { Customers }\end{array}$} \\
\hline MEET 1 & $\begin{array}{l}\text { We hold meetings where multiple members of a single customer come to hear a panel from } \\
\text { our business unit talk about our plans. }\end{array}$ \\
\hline MEET 2 & $\begin{array}{l}\text { We hold meetings where multiple members of a single customer present to us about their } \\
\text { plans. }\end{array}$ \\
\hline MEET 3 & We hold joint strategic planning meetings with our customers. \\
\hline MEET 4 & $\begin{array}{l}\text { We hold meetings where multiple customers come to hear a panel from our business unit talk } \\
\text { about our plans. }\end{array}$ \\
\hline & \\
\hline \multicolumn{2}{|l|}{$\begin{array}{l}\text { Satisfaction } \\
\text { Processes }\end{array}$} \\
\hline SAT 1 & We have many formal processes that help us capture the voice of the customer. \\
\hline SAT 2 & $\begin{array}{l}\text { We analyze customer complaint data to help us contemplate product improvements or new } \\
\text { product ideas. }\end{array}$ \\
\hline SAT 3 & $\begin{array}{l}\text { We have a formal customer satisfaction assessment system in place in our business unit that } \\
\text { helps us find areas where we need to improve. }\end{array}$ \\
\hline \multirow{2}{*}{\multicolumn{2}{|c|}{$\begin{array}{l}\text { Monitor } \\
\text { Environment }\end{array}$}} \\
\hline & \\
\hline MON 1 & $\begin{array}{l}\text { We monitor and document changes in what our customers' customers value that might affect } \\
\text { what they value from us. }\end{array}$ \\
\hline MON 4 & $\begin{array}{l}\text { We monitor and document the intensity of changes in what individual customers value (i.e., } \\
\text { how rapidly changes occur, how many changes occur at the same time, how drastic new } \\
\text { desires are from previous ones). }\end{array}$ \\
\hline MON 5 & $\begin{array}{l}\text { We try to correlate changes in our customers' environments with changes in what they value } \\
\text { from us. }\end{array}$ \\
\hline & \\
\hline \multicolumn{2}{|r|}{ 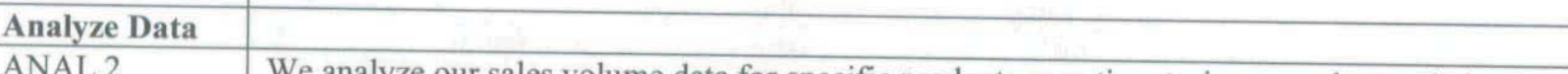 } \\
\hline ANAL 2 & $\begin{array}{l}\text { We analyze our sales volume data for specific products over time trying to understand changes } \\
\text { in the products and services customers value, not just to forecast future volume. }\end{array}$ \\
\hline ANAL 3 & We analyze secondary market data/reports looking for sales trends. \\
\hline ANAL 5 & We analyze point of sale data across time looking for changes in what our customers value. \\
\hline
\end{tabular}


APPENDIX A (continued)

\begin{tabular}{|c|c|}
\hline $\begin{array}{l}\text { Internal } \\
\text { Discussions }\end{array}$ & \\
\hline DISC 3 & $\begin{array}{l}\text { We meet internally in groups to discuss changes in what specific customers value and the } \\
\text { implications those changes have for us. }\end{array}$ \\
\hline DISC 5 & $\begin{array}{l}\text { We regularly give presentations within our organization that cover what our customers in } \\
\text { general value. }\end{array}$ \\
\hline DISC 7 & $\begin{array}{l}\text { We regularly give presentations within our organization that cover how customers' desires are } \\
\text { changing. }\end{array}$ \\
\hline & \\
\hline $\begin{array}{l}\text { Supply Chain } \\
\text { Learning }\end{array}$ & \\
\hline LRN 1 & $\begin{array}{l}\text { We try to ensure that managers are constantly learning about better ways to serve our } \\
\text { customers. }\end{array}$ \\
\hline LRN 2 & $\begin{array}{l}\text { We try to ensure that managers in our supplier organizations are learning better ways to } \\
\text { operate and serve us. }\end{array}$ \\
\hline LRN 3 & $\begin{array}{l}\text { We try to ensure that managers in our customer organizations learn better ways to manage } \\
\text { their business and work with us. }\end{array}$ \\
\hline LRN 4 & $\begin{array}{l}\text { We try to ensure that market and customer learning is shared across organizations in our } \\
\text { supply chains. }\end{array}$ \\
\hline LRN 5 & $\begin{array}{l}\text { We ensure that employees and managers change their behaviors and processes appropriately } \\
\text { as a result of new knowledge they acquire about customers. }\end{array}$ \\
\hline LRN 6 & $\begin{array}{l}\text { We ensure that employees and managers change their attitudes when needed about customers } \\
\text { and serving customers as they gain new knowledge about customers. }\end{array}$ \\
\hline Innovation & \\
\hline INN 1 & We have formal new product and service development processes. \\
\hline INN 2 & $\begin{array}{l}\text { We monitor and document the number of new product and service ideas generated in our } \\
\text { organization. }\end{array}$ \\
\hline INN 3 & We keep track of the percentage of new product and service ideas that are successful. \\
\hline $\begin{array}{l}\text { Innovation } \\
\text { Performance }\end{array}$ & 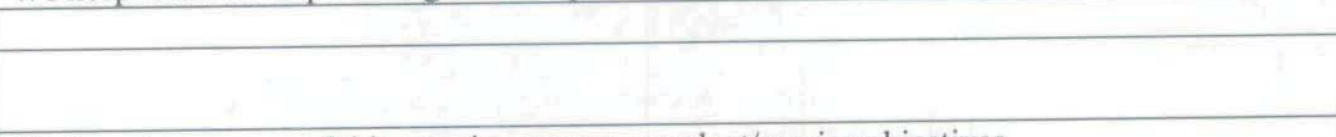 \\
\hline PERFI 1 & We have been successful in meeting our new product/service objectives. \\
\hline PERFI 2 & We generate many new product and service ideas. \\
\hline PERFI 3 & Our new product or service success rate is acceptable. \\
\hline $\begin{array}{l}\text { Overall } \\
\text { Performance }\end{array}$ & \\
\hline PERFO 1 & Our performance in general is better than our competitors'. \\
\hline PERFO 2 & We are successful at retaining the customers we want to retain. \\
\hline PERFO 3 & Our customers are very satisfied with their relationships with us. \\
\hline
\end{tabular}




\section{ABOUT THE AUTHORS}

Daniel J. Flint (Ph.D. University of Tennessee) is the Proffitt's Inc. Professor of Marketing and Associate Professor in The Department of Marketing and Logistics and Director, Marketing PhD Program at The University of Tennessee, Knoxville. He has an engineering degree from Annapolis and is well published in both marketing and logistics journals including The Journal of Marketing and the Journal of Business Logistics. Dr. Flint's expertise is in customer value management and logistics innovation.

Everth Larsson (Ph.D. Lund University) is Associate Professor and Head of Division of Engineering Logistics at Lund University, Department of Industrial Management and Logistics, Lund, Sweden. He also has earned his degrees as Licentiate of Engineering and $\mathrm{Ph} . \mathrm{D}$. at Lund University. His current research is in the areas of process based business development and logistics innovation and is the main supervisor of several Ph.D. students. In addition to journal articles and research reports, he has co-authored a book on process based business development and been co-developer of Internet-based courses in this and other areas. He has held academic leadership positions such as Vice Dean at the School of Mechanical Engineering and on a variety of boards. Dr. Larsson remains active in numerous international research networks and professional societies.

Britta Gammelgaard (Ph.D. Copenhagen Business School) is Associate Professor of Logistics and Supply Chain Management at Copenhagen Business School. Among her main research interests are logistics innovation and trends and developments of the logistics industry. Dr. Gammelgaard's work has published in international journals, such as Journal of Business Logistics, International Journal of Physical Distribution and Logistics Management, and Transportation Journal. She is a member of the Editorial Board of JBL and Associate Editor of Journal of Supply Chain Management. 